International Journal of Health Sciences
Available online at www.sciencescholar.us
Vol. 6 No. 1, April 2022, pages: 174-186
e-ISSN: 2550-696X, p-ISSN: 2550-6978
https://doi.org/10.53730/ijhs.v6n1.3684

\title{
The Advantages of Digital Applications in Public Health Services on Automation Era
}

\author{
(1) corssarate \\ Kholis Ernawati a, Budi Sulistiyo Nugroho ${ }^{\text {b }}$, Cece Suryana ${ }^{c}$, Agus Riyanto d, Endang Fatmawati e \\ Manuscript submitted: 5 September 2021, Manuscript revised: 18 December 2021, Accepted for publication: 6 January 2022
}

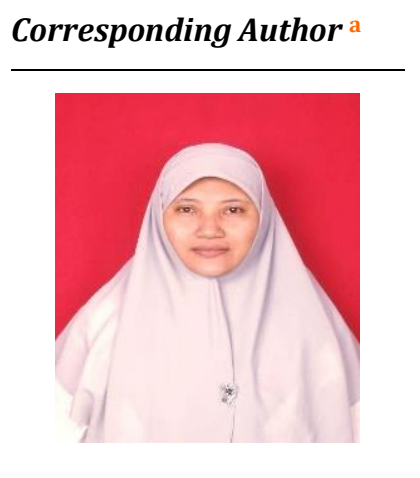

Keywords

health application;

health sector;

health services;

public health care;

public health technology;

public health;

\begin{abstract}
This study explored the advantages of using digital applications in public services in the era of automation. We have searched data in many applications, including scientific journals, books, academic residences, and many telling applications in the medical world. A series of data studies involving coding system analysis, evaluation, and interpretation, became more in-depth so that the data we found could be digested to answer this research question. Our data search was conducted electronically on secondary data published from 2010 to 2022. While the format of this study report is suitable from problem formulation to reporting on water, we chose a descriptive qualitative design with a phenomenological approach, trying to obtain the broadest possible data that is useful in answering questions of research questions. Based on the data and discussion, this study found several advantages of using digital applications in public health services in the current digital era. The reason is that digital applications have been able to innovate the work of paramedics in improving services to the public about health. Hopefully, this salary buddy will be full of supporting data for future health and technology studies.
\end{abstract}

International Journal of Health Sciences (C) 2022. This is an open access article under the CC BY-NC-ND license (https://creativecommons.org/licenses/by-nc-nd/4.0/).

\section{Contents}

Abstract

1 Introduction 175

Materials and Methods 176

3 Results and Discussions

4 Conclusion 176 181

\footnotetext{
a Universitas YARSI, Jakarta, Indonesia

b Politeknik Energi dan Mineral Akamigas, Cepu, Indonesia

c Sekolah Tinggi Hukum Sukabumi, Sukabumi, Indonesia

d STIKes Bhakti Husada, Bengkulu, Indonesia

e Universitas Diponegoro, Semarang, Indonesia
} 


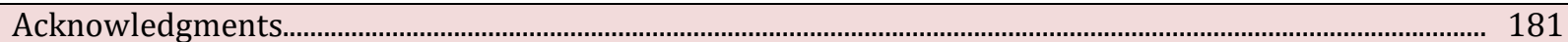

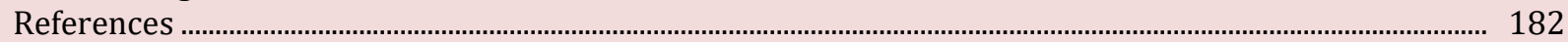

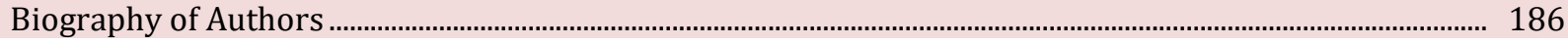

\section{Introduction}

The constitutional mandate gives the Ministry of Health of the Republic of Indonesia confidence to provide the best service, especially in the health sector, provided by superior human resources and assisted by current technological equipment (Handayani, 2021). This is because the advantages of digital applications in providing services, especially to public health, are no doubt like public services in other sectors in Indonesia (World Health Organization, 2015). Every program that is run to maximize public health services, technological innovation is the time to be optimized to improve health practices, promote technology and the role of health and think about how to provide health services plus and train health staff (Uslu et al., 2020), how to optimize the use of digital technology today which has increasingly become a mainstay in all public service sectors. Can paramedics now optimize the use of digital technology in health work? The answer is when humans can empower technology (Alvan et al., 2011). Then the work product will be faster, more accurate, and more productive.

Digital technology is indeed designed to facilitate communication in an increasingly automated era to improve the quality of public health care in Indonesia (Tayibnapis et al., 2018). Although many interpret that technology cannot be applied optimally, as policymakers certainly do not interpret that point, the most important thing is how to harmonize capabilities in technology by clarifying the vision and mission that the health department will carry out in maximizing public services made by the Ministry of Health. Digitalization system in all health operations (Troiano et al., 2014). Digital indeed refers to the management of data or signals that can be recorded or expressed, stored, transmitted, and so on in the form of a series of numerical data that may have never been before (Roco et al., 2011). So the shift from traditional manual work to alltechnology is a revolution and innovation that has begun, which is called the industrial revolution and is now entering the fourth industrial revolution which is happening where the advantages of digital technology as mentioned by the term artificial intelligence, reality robots and 3-dimensional printing very quickly shape all aspects of public services to be more focused and well created (Junginger, 2016).

Different dimensions need to be considered, including how digital can support and encourage service delivery (Koutsikouri et al., 2018). So that the existence of digitalization in the medical world can have a tremendous impact on the things that are done if the application of digital technology in various health fields will be able to improve health performance innovatively and, in turn, will provide benefits for the Indonesian people (Chang et al., 2013). When viewed from the desire to get healthy, technology can no longer offer because it is designed to make it easier for humans to serve the world of health, although challenges and views in the application, of course, exist. After all, paramedics are not ready to adapt to technology made by foreign countries that are more sophisticated than their abilities. Indonesian people apply in life in the business of life and maintain health. However, efforts to improve and adapt to technology in providing public services regarding the health of both the human environment and the natural surroundings are essential (Van den Bosch \& Bird, 2018).

When viewed from the level of public health, most Indonesians rarely go to the hospital with the assumption that public health facilities are as expected (Gneezy et al., 2011). In today's era, people often find it difficult to seek treatment with health services related to entering the management of health advertising education and the government's ways of communicating with the community (Grimshaw et al., 2012). Now with the presence of public health technology increasingly divided, it means that people who are in the middle of understanding their strengths with the help of technology can at least find adequate information with various scientific publications submitted by experts (Glanz \& Bishop, 2010), so that the existence of technology can not only be owned by medical or hospital orders, but millennials can access information (Hopkins et al., 2018). In other words, digital is currently a solution that bridges between the government and other communities (Hobbs, 2010). The existence of technology has changed the world of health, leaving the old ways that are not in contact with public services, so now the presence of technology has provided the broad spectrum needed by the community (Logue \& Grimes, 2019). The fact is that it provides a picture where

Ernawati, K., Nugroho, B. S., Suryana, C., Riyanto, A., \& Fatmawati, E. (2022). The advantages of digital

applications in public health services on automation era. International Journal of Health Sciences, 6(1), 174-186. https://doi.org/10.53730/ijhs.v6n1.3684 
the public can provide certainty and can imagine how health will perform in the digitalization era. Thus, the added value of the digitized energy program for public health, which is a means, is not considered a goal because technology is an inanimate object that cannot do anything only when the humans who operate it know the methods and benefits and advantages of digital technology in an era of all-automation (Vermesan \& Friess, 2013).

It should be emphasized again that digitalization infrastructure in medicine is a means of equipment supporting medical work for public purposes. Therefore, digital-based public health requires good regulation (Odone et al., 2021). So that it impacts the public to meet the complete service requirements, these goals have been regulated in government regulations so that the quality and accessibility can be said not to look at certain aspects but become the target of fair and professional public services. Experts recognize that the digitalization program is a technological revolution that has now added all aspects of public life (Browning et al., 2021) so that technology is seen as a tool that helps humans or medical professionals in maintaining the quality of their work and helps humans with measurable quality of health and wellbeing. Correctly so that every community can feel the benefits promised in the law (Leventhal et al., 2020). This includes people who seek treatment, such as seniors, chronically ill, and people with infectious diseases requiring very active treatment to reduce risk to others. Designed procedures and goals are planned by the creators of medical technology (Clarke \& Bennett, 2013).

\section{Materials and Methods}

This section will describe the procedure for carrying out this technology and public health literature review, starting with the formulation of problems and hypotheses and ending with reporting and conclusion of the study (Pedaste et al., 2015). This study aims to identify the advantages of digital applications in public health services in the era of automation (Whitelaw et al., 2020). So, by searching electronically for data in hundreds of published journals, books, and other proceedings and relevant website data, answering the question of the benefits of technology for public health services (Provost \& Fawcett, 2013). This study uses secondary data from evidence from previous studies that have inventoried the advantages of technology to support public health services (Maes et al., 2016). After a series of data were collected, we then involved several approaches to examine the essence and conclusions that we believe have answered this problem reasonably and progressively (Fell et al., 2020; Widana et al., 2021).

As for the procedure, we started by analyzing the data and then using coding and critically evaluating the data. Finally, we could draw another conclusion, namely, answering questions. We searched data electronically, using keywords that we did on the Google search engine, for example, from the Google Scholar application, later we found various journals such as the release of information on the World Health Organization (Beel \& Gipp, 2010), and several technology journals related to health. Meanwhile, our presentation and reporting are designed in a descriptive qualitative form where we adhere to a phenomenological approach, which is a theory or approach that seeks to search for the broadest possible data to obtain data that can provide sharper and more relevant answers (Roy et al., 2015).

\section{Results and Discussions}

\section{Digitalization in public health services}

Many digital applications have been proven to be used in the management of public health based on recommendations from health and technology experts in which health can be categorized as technological assistance, such as genomics, digital medicine, robotics, artificial intelligence, and other applications (Boulos et al., 2014). Clarifying digital applications for public health is still hampered due to the slow response to technology and the lack of esports users who can use it comprehensively can adopt Kanya to impact public health goals (Catapano et al., 2017). So the experts plan a conceptual framework for digital health applications and digital characteristics of technology that can be applied appropriately to wider use to make breakthroughs for the community in seeking health. Collaboration and technology transfer is needed to 
respond to public health challenges where digital is different from manual work in public health centers (Ratten, 2020).

This study on technology and matrices is believed to help illustrate the function of digital applications into tool solutions that assist medical tasks and may increase the value and benefits of both parties (medical people and the public who need medical services) at a time when public health practice is increasingly challenging and even demanding (Blaya et al., 2010). The reasons technology can be beneficial include increased personalization and precision in the medical field; Automation in all sectors, predictive technology, data analysis includes essential data and increasingly innovative interactions (Loebbecke \& Picot, 2015). For this application, the experts provide a model and selection of the results of previous studies. The advantages of personalization and precision are proven to be effective, although the theories and concepts of 'Public health have been carefully studied (Cohen, 2021; Leigh-Hunt et al., 2017).

It is a fact in front of our eyes that advances in digitalization technology in medical analysis and genomics greatly support the world of health to handle public medical service interventions more productively, effectively, and efficiently. It is now increasingly evident that many digital-based applications have the desired speed and completeness potential (Dwivedi et al., 2020). In addition, the education of health and medicine professionals can be personalized with virtual applications and artificial intelligence tools; For example, personalized health protection will be able to be implemented through virtual conversations with patients or fellow medical doctors utilizing various digital health trial interventions that can meet the selected audience needed through computerized patient records and services (Lall et al., 2019; Mahardika et al., 2021).

\section{Robotization in clinical service benefits}

Robotization is expected to use control frameworks and data innovation so that interactions can run naturally. Mechanization in board medical care is underway, such as emotionally supportive network choices and programmed labeling of unfavorable clinical events (Lin et al., 2014). Medication delivery framework and medical service scheduling. Moreover, electronic health record information can broadly support the robotization of answering public welfare organizations about things to tell-persistent diseases and conditions (Coeckelbergh et al., 2016). Expectations from technology and massive electronic information from multiple sources (health information as well as meteorological forecasts, online media, and geographic data frame information) are used to illuminate AI and non-AI forecasting models that can identify or anticipate ahead of schedule, for example, inhospitable opportunity, contamination related to medical care, episodes of infectious disease or health emergencies, consider appropriate precautions and early intercession (Naser et al., 2021; Parmin et al., 2020).

In clinical practice, rendered and unaided AI-based models are progressively used for mechanical image translation; generally, they can be applied to screening programs (Zhang, 2017). Information inquiry: Digital tools achieve transformations in selecting and sharing information and testing, with significant applications for general welfare (Walsh \& Lynch, 2018). First of all, how much information is accessible has grown dramatically. A dire measure of organized, semi-organized, and unstructured information is excavated for data and used in AI projects and other advanced investigative applications, both in examinations and general welfare practice (Kahn et al., 2010). Second, information is shared quickly and communicated (Kahn et al., 2010). Telemedicine or continuous surveillance applications) Furthermore, connecting to multiple sources of information with significant possible applications for board welfare, general health monitoring, public health insight announcements, and checks, among others (Harmsen et al., 2013).

Digital settings that help patients and the population as a whole create their wellbeing data20 and, in particular from a general wellbeing perspective, to coordinate and manage them, with a significant effect on strengthening tolerance (Lomas et al., 2017). In addition, mobile phone applications support self-management of social hazard factors (e.g., active work) with significant preventive effects. The Internet and web-based media present associations in correspondence about wellbeing (rather than correspondence from traditional media where it is difficult to share or comment on substance); this builds on the dynamic work of the population as a whole in welfare choices (Häusermann, 2010). The points mentioned above can support progress and advancement in general health practice, health training and training, in general, health strategies both within and outside the health field, and in public health research (Waheed et al., 2015).

Ernawati, K., Nugroho, B. S., Suryana, C., Riyanto, A., \& Fatmawati, E. (2022). The advantages of digital applications in public health services on automation era. International Journal of Health Sciences, 6(1), 174-186. https://doi.org/10.53730/ijhs.v6n1.3684 
Our hypothetical calculation system made it possible to distill the potential advantages and general medical benefits. Digitization brings the barriers, harms, and potential attachments that digitization presents (Kurpjuweit et al., 2021). In various supplementation papers, Digitization supports progress from improvement to avoidance. Perhaps the most significant benefit of computerized health is that it supports the change from therapy to anticipation; This applies to both essential and optional countermeasures (David \& Nielsen, 2016). As before, as perceived by WHO, advances in computerized health offer a way of selfmonitoring of health that significantly influences the spread of social hazard factors. For example, regular audits look at the possible benefits of computerized health mediation on cardiovascular disease outcomes and risk factors and reveal telemedicine, electronic methodologies, e-mail, telephone, multipurpose applications, messaging, and mediation of sensor-based observations to reduce the occurrence of hospitalizations and deaths and for lowering BMI and body weight, contrast and typical treatments (David \& Nielsen, 2016).

\section{Public government assistance digitization framework}

Digitization of the overall government assistance ought not to be treated as one more part to be brought together in the distribution center yet ought to be considered on the more extensive worth chain to accomplish the ideal government assistance and thriving of society. Unquestionably, if, as the OECD underlines, electronic development is reshaping the limits of society, a successful European framework for the Digitization of the benefit of all ought to incorporate every one of the marks of help nitty-gritty.

\section{The political obligation of governments}

The European Commission has as of late circulated a basic administrative report that gives an exact bearing to EU practice to help the Digital Transformation of Health and Care for the upcoming years (Wille, 2013). The EU Communication on the Digital Transformation of Health and Care in the Digital Single Market perceives three necessities: (I) inhabitants' protected admittance to their prosperity data across the EU; (ii) Personalized consideration through a typical European data system and (iii) Citizen strengthening with cutting edge instruments for customer scrutinize and individual-centered judgment. In 2018, the WHO Regional Office for Europe sent a WHO/European push for the Digitization of Health Systems as a neighborhood European action mentioning to pass the WHA Resolution on mHealth/prosperity, further uplifting the Member States to zero in on improving, surveying, executing, upgrading and more noticeable utilization of modernized developments, as a method for advancing fair, evenhanded and customary acknowledgment of clinical consideration for all. European nations set up open eHealth at the Member State level and progressed government assistance plans and strategies. The latest methodical evaluation drove in 2016 declared that $74 \%$ of European Member States with comprehensive government assistance consideration have general level courses of action or techniques on eHealth (Who Regional Office for Europe, 2018).

\section{Normalization and managerial constructions in pubic health care}

Political commitments for mechanized public government assistance should be changed into an arrangement of guidelines and organization at the European and public levels. At the EU level, the eHealth Network, made under article 14 of Directive 2011/24/EU, builds up the standards for interoperability of electronic wellbeing structures and use of eHealth among the Member States (Jacquot, 2015). Another examination concerning the general guideline of electronic wellbeing records in the EU Member States reports critical contrasts in administrative frameworks across Europe at the Member State level. Likewise, the ampleness of explicit open systems empowers the operationalization of guidelines. Public law is altogether different. The data shows that the EU Member States are digitizing public clinical consideration structures at something else altogether. The Digital Health Index, which studies the government assistance status of created nations, records Estonia and

Denmark as the most exceptional in Europe while different nations fall a long way behind. Additionally, inside nations, the Digitization of general wellbeing administrations changes by area and single wellbeing facility (Neamţu et al., 2019). 
Monetary endeavor

The cutting edge deals with any consequences regarding prosperity requires a monetary endeavor. In 2011, the European Commission's Joint Research Center (JRC) communicated that sponsoring was central to stimulating and propelling e-prosperity drives (Maduro et al., 2018). Today, according to another examination, the overall progressed clinical consideration market addresses $\$ 179.6$ billion and is depended upon to create to $\$ 536.6$ billion preceding the completion. This tends to a $173.3 \%$ addition stood out from 2016. With the US Canada beating the European Union, a European Commission reports that Europe addresses $30 \%$ of the overall mHealth market, creating at the speediest speed, stood out from other regions. In cutting-edge prosperity, the critical business players are media correspondences associations and convenient directors, essential ICT, and equipment social affairs (Savinova et al., 2021). Makers of clinical/looking at contraptions and stages, the medication business, and startups. Apart from private financial interests, interest in automated prosperity should be joined with institutional interests. It should come from regional and public prosperity structure spending plans, similarly as the European Union is legitimate and meets general prosperity incorporation targets (Keating et al., 2015).

Moreover, overall prosperity, the assurance, and capacity of automated prosperity should be cultivated, expecting it follows general prosperity goals and not only be coordinated by market impacts (Bhat et al., 2021). Assessing public spending on cutting-edge general prosperity in Europe is hampered by the heterogeneity of the prosperity system, contingent upon different bodies with free commitments, interests, and characteristics. Regardless, it is fundamental that the overall population prosperity progressed framework is maintained by adequate public sponsoring (Habitat, 2013).

\section{Preparing and schooling}

How might tomorrow's general wellbeing labor force be ready to act in a computerized workplace? We expect, as a rule, digitalization to change the jobs and elements of staff (Supplementary Appendix to Master's Degree for the inventive portrayal of future general wellbeing experts) to move the limits of the capabilities they should have (Schwab, 2017). Also, general wellbeing personnel's meaning will be extended to incorporate experts with specialized foundations (for example, informatics and specialists) to help execute computerized programs for various general wellbeing purposes (Papadimitriou et al., 2020). Schooling and preparing in general wellbeing ought to go in this direction. All the more critically, schooling and preparing ought not to furnish directions on the most proficient method to manage future advancements; notwithstanding, it should mean to expand the computerized education of professionals to guarantee they will want to accept development. Although no deliberate appraisal has been completed, practical information from Europe shows that computerized wellbeing components are still seldom remembered for postgraduate and postgraduate general wellbeing programs, the most progressive model being in the UK (Maxwell et al., 2018). Be that as it may, the educational program is advancing quickly; clinical schools incorporate computerized wellbeing credits in clinical and non-clinical modules and choose colleges that offer double degrees in Medicine and Engineering.

\section{Research and development}

Digitization in general wellbeing ought not to be an unfilled motto, yet its preparation, presentation, and execution should be educated by proof. Notwithstanding fortifying political responsibility and expanding monetary interest in advanced wellbeing innovations, research results on their application to general wellbeing are 'still in their earliest stages (Jones, 2015). The hypothetical advantages and benefits of computerized general wellbeing arrangements in the above segments are far from being quantitatively evaluated in various settings. In any case, there is interest in building and assembling proof on the point as shown by the 2018-2020 Horizon 2020 Work Program on 'Computerized Transformation in Health and Care covering 21 themes, all with projected general wellbeing impacts and the send-off of friend diaries (Raschke, 2019), a new devoted review. Research on advanced open wellbeing is hampered by various plan issues, including the decision of suitable benchmark groups, the meaning of clinical results, relevant associations, and cycles, capacity to move discoveries to various settings, without failing to remember the should be

Ernawati, K., Nugroho, B. S., Suryana, C., Riyanto, A., \& Fatmawati, E. (2022). The advantages of digital applications in public health services on automation era. International Journal of Health Sciences, 6(1), 174-186. https://doi.org/10.53730/ijhs.v6n1.3684 
straightforward and autonomous. Functional exploration should be completed drawing on wellbeing administrations and logical biomedical informatics for studies on computerized wellbeing interventions' adequacy, viability, and cost-adequacy (Easterling, 2015).

The impact of electronic game plans on prosperity and clinical consideration, once executed, ought to be assessed and assessed. It is fundamental to enlighten course and resource dispersion (Bhat et al., 2021). In 2019, the European Commission's Panel of Experts on the ideal way to effectively place assets into Health (EXPH) provided a report giving guidance on the most capable technique to, indeed, overview the impact of the moderate difference in healthcare (Urinov et al., 2021; Nataliia et al., 2021). In more detail, the Panel of Experts focused on that at the center and the close by level, decisions to take on, use, or displace electronic prosperity organizations should be established on data on their show according to the objectives of the prosperity structure. EXPH follows the available designs and proficient procedures for assessing the impact of the dynamic difference in clinical consideration on different perspectives, including induction to mind, clinical and legitimate outcomes, patient help, use of resources, and acceptability. In this remarkable not entirely set in stone to set up a European store for appraisal strategies and reports, it is fundamental to consider how best to change the Health Technology Assessment (HTA) model to assess mechanized tasks. Regardless of HTA's progressed game plans before their show, noticing execution should be finished, researching how prosperity and prosperity systems are developing, similarly resulting from Digitization (Loebbecke \& Picot, 2015).

\section{Planning and tutoring}

How should the upcoming general prosperity workforce be prepared to act in an electronic work environment? When in doubt, we expect the occupation of EUPHA to drive the shift towards digitizing general prosperity (Duderstadt, 2010). EUPHA, set up in 1992, is a strong, available, and exhaustive science-based general prosperity association, by and by including 86 people from countries in the WHO European Region. As the umbrella relationship for general prosperity relationship, with an extraordinary driving circumstance in Europe, its essential objective is to work with and start a strong voice from the overall prosperity neighborhood growing the porousness of confirmation and building up the restriction of general prosperity professionals (Iversen \& Soskice, 2019).

This mission supports the most widely recognized approach to digitizing general prosperity. Convincing ones have been recognized in the need areas of interest (Lueddeke, 2015). In particular, EUPHA is centered around ensuring that electronic capacity is 'used' to pursue and meet Europe's overall prosperity goals of additional creating prosperity and success and confining prosperity contrasts. Bracing undertakings towards useful maltreatment, EUPHA's exercises across Europe increment the benefit of advancing undertakings to achieve convincing, legitimate, open, ensured, and fair digitalization of general prosperity by accomplices nearby and state, in broad daylight and worldwide affiliations, similarly as by lone clinical consideration capable. A few pieces of EUPHA's exercises on general electronic prosperity are finished regarding the European Public Health Conference (EPH) and inside the practical sections of EUPHA (Zeegers Paget et al., 2020).

Seeing the meaning of the rhythmic movement and future occupation of Digitization in everyday prosperity and developing the improving discussions stimulated by the EPH legitimate gatherings reported the underpinning of the EUPHA effective Section on Digital Health has not set in stone to join researchers, policymakers, and experts across the globe (Plueddemann, 2012). Europeans are working on general electronic prosperity for data sharing and breaking point building. This part will work across capacities, disciplines, and settings to apply the fundamental objections of EUPHA48 to the field of cutting-edge prosperity. This section will develop support on, accumulate, produce, and shatterproof concerning the necessity and the impact of mechanized courses of action on broad prosperity. It will join a middle social affair of experts in picked pieces of cutting-edge prosperity, work with general level best practice exchanges, and vitalize European-level conversation to place electronic general prosperity high on the EU's course of action, assessment, and guidance plan. The execution of the EUPHA48 Strategy created by the Digital Health Section, by single space, is accounted for (Bucci et al., 2019). 


\section{Conclusion}

We will run a series of studies later; we will take the leading National Examination which we have described in the results and discussion section, with the aim of the study being to obtain authentic evidence from the results of previous studies that discussed the advantages of digital applications in the world of public services in the era of all automation. Through studies and evidence supported by previous studies, we believe that the data we have presented has answered this study's questions and problems is a valid and tested principle. The core part that we describe here, among others, we mention that digitalization in public health services is proven to be very beneficial for both medical and health service recipient factories in an increasingly digital era. The medical world applies this digital solution is none other than because this application has several advantages and advantages that have been able to innovate medical tasks to improve the quality of public health services.

Furthermore, we also describe how na2o titration in clinical services is profitable (MacMillan et al., 2005). This means that robotics in all health practices is genuinely an innovation through data, which can happen because the already excellent automatic breast milk is designed to deal with the problem of how public services in health are becoming more and more challenging than eating a little bit. However, various electronics it has supported and supported medical work both in the medical education environment and in practice. Next is how the government helps digitize with a work format whose reliability has been tested in innovating work that was previously very difficult. However, after Digitization has penetrated the sector, especially in the medical world, this is very beneficial for both the government and the public who receive health services in an all-digital era.

However, it turns out that there is also political communication from the government, which requires that as a public service, it must provide transformation in all fields, especially in the field of health services where with all the advantages possessed by the diesel engine, this will improve public services in health, not only in European and American countries but in other countries where the digitalization system is slowly becoming something that is used. Then we also see that public health care can be done with the help of first a political commitment to public services then supported by adequate technology workers so that the assistance provided by the government to the public achieves the desired target. Likewise, with the presence of technology, the government will save tremendous funds because of the position that has been handled by humans with all the fuss but present all data and tasks will become easy.

Then how to prepare educators for the medical world that will help when they are in the field of preparation for this repair is necessary because technological innovation will occur without superior human resources. We also mentioned how this digitalization would run smoothly if supported by studies and developments that never stop; therefore, information from the medical world will continue when the world of study and development goes hand in hand. We include how medical professionals should plan rather than train to carry out all tasks supported by technology and commitments. We believe and trust the data we display; apart from having advantages, there are also many weaknesses and limitations.

\section{Acknowledgments}

All authors express an excellent thank you for all feedback and financial support.

Ernawati, K., Nugroho, B. S., Suryana, C., Riyanto, A., \& Fatmawati, E. (2022). The advantages of digital applications in public health services on automation era. International Journal of Health Sciences, 6(1), $174-186$. https://doi.org/10.53730/ijhs.v6n1.3684 


\section{References}

Alvan, G., Edlund, C., \& Heddini, A. (2011). The global need for effective antibiotics - a summary of plenary presentations. Drug Resistance Updates, 14(2), 70-76. https://doi.org/10.1016/j.drup.2011.01.007

Beel, J., \& Gipp, B. (2010). Academic search engine spam and Google Scholar's resilience against it. The Journal of Electronic Publishing: JEP, 13(3).

Bhat, A. P., Dumore, N. G., Dhoble, S. J., \& Rewatkar, K. G. (2021). Clinical Decision-Making and Predicting Patient Trajectories. In Advanced Prognostic Predictive Modelling in Healthcare Data Analytics (pp. 267311). Springer, Singapore.

Blaya, J. A., Fraser, H. S., \& Holt, B. (2010). E-health technologies show promise in developing countries. Health Affairs, 29(2), 244-251.

Boulos, M. N. K., Brewer, A. C., Karimkhani, C., Buller, D. B., \& Dellavalle, R. P. (2014). Mobile medical and health apps: state of the art, concerns, regulatory control and certification. Online journal of public health informatics, 5(3), 229.

Browning, L., Colling, R., Rakha, E., Rajpoot, N., Rittscher, J., James, J. A., ... \& Verrill, C. (2021). Digital pathology and artificial intelligence will be key to supporting clinical and academic cellular pathology through COVID19 and future crises: the PathLAKE consortium perspective. Journal of clinical pathology, 74(7), 443-447.

Bucci, S., Schwannauer, M., \& Berry, N. (2019). The digital revolution and its impact on mental health care. Psychology and Psychotherapy: Theory, Research and Practice, 92(2), 277-297.

Catapano, A. L., Graham, I., De Backer, G., Wiklund, O., Chapman, M. J., Drexel, H., ... \& Cooney, M. T. (2017). 2016 ESC/EAS guidelines for the management of dyslipidaemias. Revista espanola de cardiologia (English ed.), $70(2), 115$.

Chang, M. C., Al-Samarrai, S., Shaeffer, S., Ragatz, A. B., De Ree, J., \& Stevenson, R. (2013). Teacher reform in Indonesia: The role of politics and evidence in policy making. World Bank Publications.

Clarke, L. H., \& Bennett, E. V. (2013). Constructing the moral body: self-care among older adults with multiple chronic conditions. Health:, 17(3), 211-228.

Coeckelbergh, M., Pop, C., Simut, R., Peca, A., Pintea, S., David, D., \& Vanderborght, B. (2016). A survey of expectations about the role of robots in robot-assisted therapy for children with ASD: ethical acceptability, trust, sociability, appearance, and attachment. Science and engineering ethics, 22(1), 47-65.

Cohen, M. S. (2021). Monoclonal antibodies to disrupt progression of early covid-19 infection. New England Journal of Medicine, 384(3), 289-291.

David, R. A., \& Nielsen, P. (2016). Defense science board summer study on autonomy. Defense Science Board Washington United States.

Duderstadt, J. J. (2010). A master plan for higher education in the Midwest.

Dwivedi, Y. K., Hughes, D. L., Coombs, C., Constantiou, I., Duan, Y., Edwards, J. S., ... \& Upadhyay, N. (2020). Impact of COVID-19 pandemic on information management research and practice: Transforming education, work and life.International Journal of Information Management, 55, 102211. https://doi.org/10.1016/j.ijinfomgt.2020.102211

Easterling, L. (2015). Strategies nurse managers used to offset challenges during electronic medical records implementation: A case study (Doctoral dissertation, University of Phoenix).

Fell, M. J., Pagel, L., Chen, C. F., Goldberg, M. H., Herberz, M., Huebner, G. M., ... \& Hahnel, U. J. (2020). Validity of energy social research during and after COVID-19: challenges, considerations, and responses. Energy Research \& Social Science, 68, 101646. https://doi.org/10.1016/j.erss.2020.101646

Glanz, K., \& Bishop, D. B. (2010). The role of behavioral science theory in development and implementation of public health interventions. Annual review of public health, 31, 399-418.

Gneezy, U., Meier, S., \& Rey-Biel, P. (2011). When and why incentives (don't) work to modify behavior. Journal of economic perspectives, 25(4), 191-210.

Grimshaw, J. M., Eccles, M. P., Lavis, J. N., Hill, S. J., \& Squires, J. E. (2012). Knowledge translation of research findings. Implementation science, 7(1), 1-17.

Habitat, U. N. (2013). State of the world's cities 2012/2013: Prosperity of cities. Routledge.

Handayani, O. (2021). Kontroversi Sanksi Denda Pada Vaksinasi Covid-19 Dalam Perspektif Undang-Undang No. 36 Tahun 2009 Tentang Kesehatan. KRTHA BHAYANGKARA, 15(1), 84-102.

Harmsen, I. A., Doorman, G. G., Mollema, L., Ruiter, R. A., Kok, G., \& de Melker, H. E. (2013). Parental information-seeking behaviour in childhood vaccinations. BMC Public Health, 13(1), 1-10. 
Häusermann, S. (2010). The politics of welfare state reform in continental Europe: Modernization in hard times. Cambridge University Press.

Hobbs, R. (2010). Digital and Media Literacy: A Plan of Action. A White Paper on the Digital and Media Literacy Recommendations of the Knight Commission on the Information Needs of Communities in a Democracy. Aspen Institute. 1 Dupont Circle NW Suite 700, Washington, DC 20036.

Hopkins, L., Hampton, B. S., Abbott, J. F., Buery-Joyner, S. D., Craig, L. B., Dalrymple, J. L., ... \& Page-Ramsey, S. M. (2018). To the point: medical education, technology, and the millennial learner. American journal of obstetrics and gynecology, 218(2), 188-192. https://doi.org/10.1016/j.ajog.2017.06.001

Iversen, T., \& Soskice, D. (2019). Democracy and prosperity. Princeton University Press.

Jacquot, S. (2015). Transformations in EU gender equality: From emergence to dismantling. Springer.

Jones, N. (2015). Governing by virtue: lord burghley and the management of Elizabethan England. OUP Oxford.

Junginger, S. (2016). Transforming Public Services by Design: Re-orienting policies, organizations and services around people. Routledge.

Kahn, J. G., Yang, J. S., \& Kahn, J. S. (2010). 'Mobile'health needs and opportunities in developing countries. Health affairs, 29(2), 252-258.

Keating, M., Hooghe, L., \& Tatham, M. (2015). Bypassing the nation-state?: Regions and the EU policy process. In European Union (pp. 445-466). Routledge.

Koutsikouri, D., Lindgren, R., Henfridsson, O., \& Rudmark, D. (2018). Extending digital infrastructures: a typology of growth tactics. Journal of the Association for Information Systems, 19(10), 2.

Kurpjuweit, S., Schmidt, C. G., Klöckner, M., \& Wagner, S. M. (2021). Blockchain in additive manufacturing and its impact on supply chains. Journal of Business Logistics, 42(1), 46-70.

Lall, P., Rees, R., Law, G. C. Y., Dunleavy, G., Cotič, Ž., \& Car, J. (2019). Influences on the implementation of mobile learning for medical and nursing education: qualitative systematic review by the digital health education collaboration. J Med Internet Res, 21(2), e12895.

Leigh-Hunt, N., Bagguley, D., Bash, K., Turner, V., Turnbull, S., Valtorta, N., \& Caan, W. (2017). An overview of systematic reviews on the public health consequences of social isolation and loneliness. Public health, 152, 157-171. https://doi.org/10.1016/j.puhe.2017.07.035

Leventhal, H., Nerenz, D. R., \& Steele, D. J. (2020). Illness representations and coping with health threats (pp. 219-252). Routledge.

Lin, P., Abney, K., \& Bekey, G. A. (Eds.). (2014). Robot ethics: the ethical and social implications of robotics. MIT press.

Loebbecke, C., \& Picot, A. (2015). Reflections on societal and business model transformation arising from digitization and big data analytics: A research agenda. The Journal of Strategic Information Systems, 24(3), 149-157.

Logue, D., \& Grimes, M. (2019). Platforms for the people: Enabling civic crowdfunding through the cultivation of institutional infrastructure. Strategic Management Journal.

Lomas, T., Medina, J. C., Ivtzan, I., Rupprecht, S., Hart, R., \& Eiroa-Orosa, F. J. (2017). The impact of mindfulness on well-being and performance in the workplace: an inclusive systematic review of the empirical literature. European Journal of Work and Organizational Psychology, 26(4), 492-513.

Lueddeke, G. (2015). Global population health and well-being in the 21st century: toward new paradigms, policy, and practice. Springer Publishing Company.

MacMillan, K., Money, K., Money, A., \& Downing, S. (2005). Relationship marketing in the not-for-profit sector: an extension and application of the commitment-trust theory. Journal of business research, 58(6), 806-818. https://doi.org/10.1016/j.jbusres.2003.08.008

Maduro, M. P., Pasi, G., \& Misuraca, G. (2018). Social impact investment in the EU. Financing strategies and outcome oriented approaches for social policy innovation: narratives, experiences, and recommendations. JRC Working Papers, (JRC111373).

Maes, J., Liquete, C., Teller, A., Erhard, M., Paracchini, M. L., Barredo, J. I., ... \& Lavalle, C. (2016). An indicator framework for assessing ecosystem services in support of the EU Biodiversity Strategy to 2020. Ecosystem services, 17, 14-23. https://doi.org/10.1016/j.ecoser.2015.10.023

Mahardika, I. M. R., Suyasa, I. G. P. D., Kamaryati, N. P., \& Wulandari, S. K. (2021). Health literacy is strongest determinant on self-monitoring blood glucose (SMBG) type 2 DM patients during COVID-19 pandemic at public health centre in Tabanan Regency. International Journal of Health \& Medical Sciences, 4(3), 288-297.

Ernawati, K., Nugroho, B. S., Suryana, C., Riyanto, A., \& Fatmawati, E. (2022). The advantages of digital applications in public health services on automation era. International Journal of Health Sciences, 6(1), 174-186. https://doi.org/10.53730/ijhs.v6n1.3684 
Maxwell, W. D., Fabel, P. H., Diaz, V., Walkow, J. C., Kwiek, N. C., Kanchanaraksa, S., ... \& Bookstaver, P. B. (2018). Massive open online courses in US healthcare education: practical considerations and lessons learned from implementation. Currents in Pharmacy Teaching and Learning, 10(6), 736-743. https://doi.org/10.1016/j.cptl.2018.03.013

Naser, M., Mohamed, M. N., \& Shehata, L. H. (2021). Advanced Strategies Against COVID-19 Review. International Journal of Progressive Sciences and Technologies, 26(1), 395-412.

Nataliia, V., Barzylovych, A., Zabolotna, A., Boiko, M., \& Rybchych, I. (2021). Healthcare facilities management in digitalization context. International Journal of Health Sciences, 5(3), 429-440. https://doi.org/10.53730/ijhs.v5n3.1773

Neamţu, D. M., Hapenciuc, C. V., \& Bejinaru, R. (2019). The impact of digitalization on business sector development in the knowledge economy. In Proceedings of the international conference on business excellence (Vol. 13, No. 1, pp. 479-491).

Odone, A., Gianfredi, V., Sorbello, S., Capraro, M., Frascella, B., Vigezzi, G. P., \& Signorelli, C. (2021). The Use of Digital Technologies to Support Vaccination Programmes in Europe: State of the Art and Best Practices from Experts' Interviews. Vaccines, 9(10), 1126.

Papadimitriou, E., Schneider, C., Tello, J. A., Damen, W., Vrouenraets, M. L., \& Ten Broeke, A. (2020). Transport safety and human factors in the era of automation: What can transport modes learn from each other?. Accident Analysis \& Prevention, 144, 105656. https://doi.org/10.1016/j.aap.2020.105656

Parmin, P., Suarayasa, K., \& Wandira, B. A. (2020). Relationship between quality of service with patient loyality at general polyclinic of kamonji public health center. International Journal of Health \& Medical Sciences, 3(1), 86-91.

Pedaste, M., Mäeots, M., Siiman, L. A., De Jong, T., Van Riesen, S. A., Kamp, E. T., ... \& Tsourlidaki, E. (2015). Phases of inquiry-based learning: Definitions and the inquiry cycle. Educational research review, 14, 47-61. https://doi.org/10.1016/j.edurev.2015.02.003

Plueddemann, J. E. (2012). Leading across cultures: Effective ministry and mission in the global church. InterVarsity Press.

Provost, F., \& Fawcett, T. (2013). Data science and its relationship to big data and data-driven decision making. Big data, 1(1), 51-59.

Raschke, C. (2019). Neoliberalism and Political Theology: From Kant to Identity Politics. Edinburgh University Press.

Ratten, V. (2020). Coronavirus (Covid-19) and the entrepreneurship education community. Journal of Enterprising Communities: People and Places in the Global Economy.

Roco, M. C., Harthorn, B., Guston, D., \& Shapira, P. (2011). Innovative and responsible governance of nanotechnology for societal development. In Nanotechnology research directions for societal needs in 2020 (pp. 561-617). Springer, Dordrecht.

Roy, K., Zvonkovic, A., Goldberg, A., Sharp, E., \& LaRossa, R. (2015). Sampling richness and qualitative integrity: Challenges for research with families. Journal of Marriage and Family, 77(1), 243-260.

Savinova, N., Berehova, M., Yanchytska, K., Stelmah, N., Biliuk, O., \& Kasatkina-Kubyshkina, O. (2021). ICT role during COVID-19 pandemic in lifelong learning for disabilities. International Journal of Health Sciences, 5(3), 594-604. https://doi.org/10.53730/ijhs.v5n3.2572

Schwab, K. (2017). The fourth industrial revolution. Currency.

Tayibnapis, A. Z., Wuryaningsih, L. E., \& Gora, R. (2018). Indonesia's Efforts to Achieve Globally Competitive Human Resources. International Journal of Humanities and Social Science Invention (IJHSSI), 7(8), 01-06.

Troiano, R. P., McClain, J. J., Brychta, R. J., \& Chen, K. Y. (2014). Evolution of accelerometer methods for physical activity research. British journal of sports medicine, 48(13), 1019-1023.

Urinov, M., Alikulova, N., Zukhritdinova, D., Usmonov, M., \& Urinov, R. (2021). Clinical, laboratory and instrumental indicators in patients who have undergone COVID-19. International Journal of Health Sciences, 5(3), 403-415. https://doi.org/10.53730/ijhs.v5n3.1719

Uslu, B. Ç., Okay, E., \& Dursun, E. (2020). Analysis of factors affecting IoT-based smart hospital design. Journal of Cloud Computing, 9(1), 1-23.

Van den Bosch, M., \& Bird, W. (Eds.). (2018). Oxford textbook of nature and public health: The role of nature in improving the health of a population. Oxford University Press. 
Vermesan, O., \& Friess, P. (Eds.). (2013). Internet of things: converging technologies for smart environments and integrated ecosystems. River publishers.

Waheed, W., Hughes-Morley, A., Woodham, A., Allen, G., \& Bower, P. (2015). Overcoming barriers to recruiting ethnic minorities to mental health research: a typology of recruitment strategies. BMC psychiatry, 15(1), 111.

Walsh, B., \& Lynch, M. (2018). Evolution and selection of quantitative traits. Oxford University Press.

Whitelaw, S., Mamas, M. A., Topol, E., \& Van Spall, H. G. (2020). Applications of digital technology in COVID-19 pandemic planning and response. The Lancet Digital Health. https://doi.org/10.1016/S2589$7500(20) 30142-4$

Widana, I.K., Sumetri, N.W., Sutapa, I.K., Suryasa, W. (2021). Anthropometric measures for better cardiovascular and musculoskeletal health. Computer Applications in Engineering Education, 29(3), 550561. https://doi.org/10.1002/cae.22202

Wille, A. (2013). The normalization of the European Commission: Politics and bureaucracy in the EU executive. OUP Oxford.

Zeegers Paget, D., Nagyova, I., Zeegers Paget, D., Leyland, A., Kluge, H. H. P., Barnhoorn, F., ... \& Barnhoorn, F. (2020). European public health news. European journal of public health, 30(4), 842-844.

Zhang, A. (2017). Simultaneous interpreting (SI): the holy grail of artificial intelligence-an SI practitioner's perspective. Lebende Sprachen, 62(2), 253-268.

Ernawati, K., Nugroho, B. S., Suryana, C., Riyanto, A., \& Fatmawati, E. (2022). The advantages of digital applications in public health services on automation era. International Journal of Health Sciences, 6(1), 174-186. https://doi.org/10.53730/ijhs.v6n1.3684 


\section{Biography of Authors}

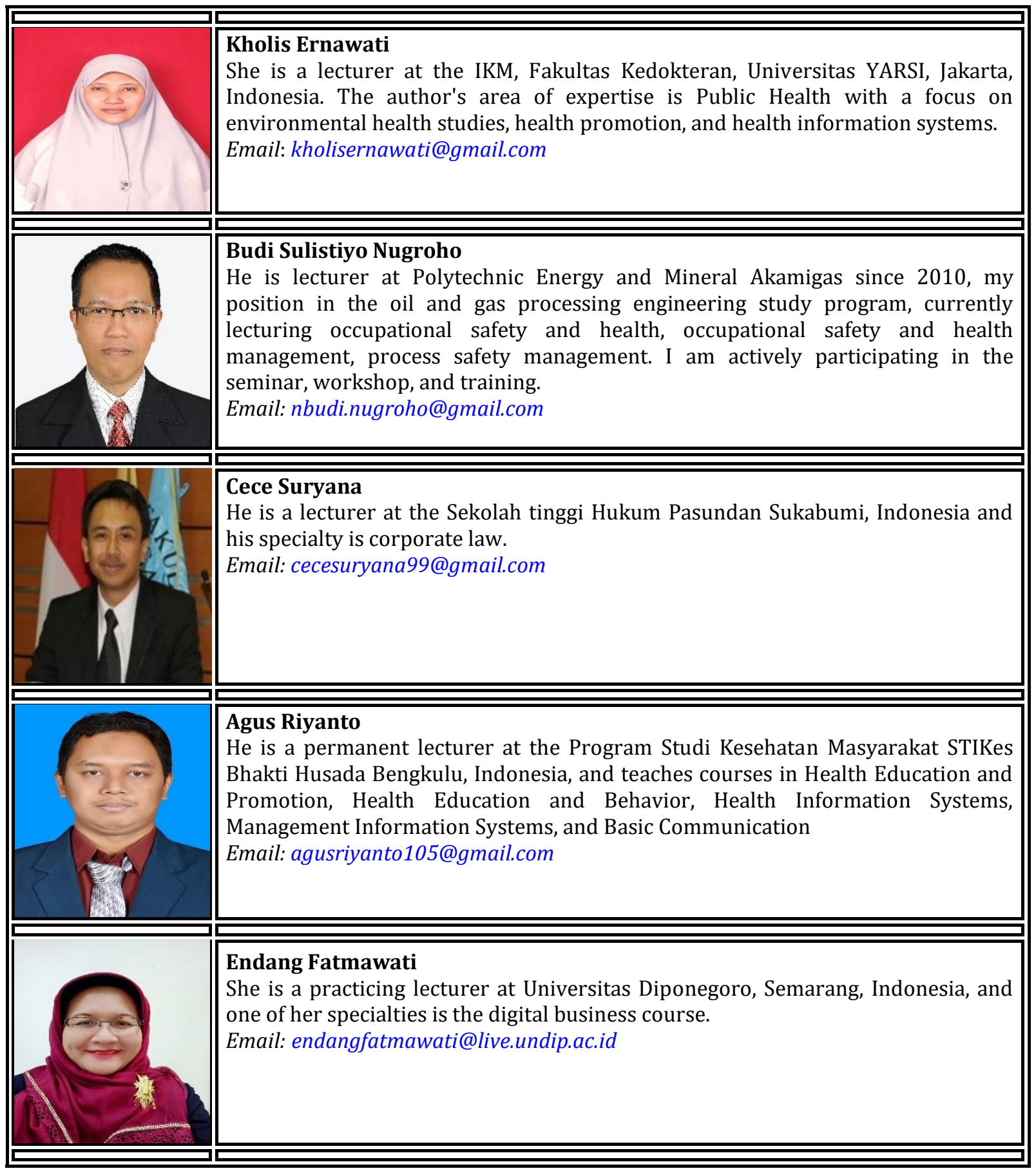

